\title{
Post-Traumatic Stress Disorder, Alexithymia and Somatoform Dissociation in Patients with Fibromyalgia
}

\section{Fibromiyalji Hastalarında Travma Sonrası Stres Bozukluğu, Aleksitimi ve Somotoform Dissosiyasyon}

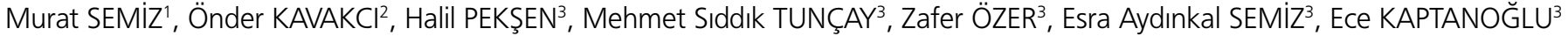 \\ 'Department of Psychiatry, Gaziosmanpaşa University, Tokat, Turkey \\ ${ }^{2}$ Department of Psychiatry, Cumhuriyet University Faculty of Medicine, Sivas, Turkey \\ ${ }^{3}$ Department of Physical Medicine and Rehabilitation, Cumhuriyet University Faculty of Medicine, Sivas, Turkey
}

\begin{abstract}
Objective: We investigated the prevalence of post-traumatic stress disorder, alexithymia, and somatoform dissociative symptoms in patients with fibromyalgia (FM).

Material and Methods: Fifty-six consecutive patients with FM admitted to the outpatient department were enrolled in this study after providing informed consent. Forty-six patients with rheumatoid arthritis (RA) were enrolled as controls. Participants completed the Somatoform Dissociation Questionnaire (SDQ), the Post-traumatic Diagnostic Scale (PDS), the Toronto Alexithymia Scale (TAS), and The Childhood Trauma Questionnaire (CTQ). The impact of FM was measured with the Fibromyalgia Impact Questionnaire (FIQ).

Results: The number of patients reporting at least one traumatic event was higher in the FM $(19,33.9 \%)$ than in the RA $(6,13 \%)(X 2=5.9, p=0.015)$ group. Post-traumatic stress disorder (PTSD) was found in six $(10.7 \%)$ of the 56 subjects with FM. In the RA group, no patients met the criteria for PTSD. Current PTSD prevalence was higher in the FM than in the RA group. Among those with FM group and traumatic experiences, FIQ scores were higher in patients with than without PTSD $(p=0.02)$. Additionally, a positive correlation between traumatic experiences and use of analgesics $(r=0.415$, $\mathrm{p}=0.002$ ) was also observed. FM patients had significantly higher scores than did RA patients on the CTQ, SDQ and TAS.

Conclusion: The results of this study indicate that PTSD, alexithymia, and dissociative symptoms positively influence the levels of pain and FM-related disability in FM patients. Treatment strategies may be developed to manage psychiatric conditions in fibromyalgia.
\end{abstract}

Key Words: Fibromyalgia, post-traumatic stress disorder, alexithymia, somatoform dissociation
Özet

Amaç: Çalışmamızda Fibromiyalji (FM) hastalarında Travma Sonrası Stres Bozukluğu (TSSB), aleksitimi ve dissosiyatif semptomların yaygınlığını araştırdık.

Gereç ve Yöntemler: Polikliniğe başvuran $56 \mathrm{FM}$ hastası bilgilendirildikten sonra çalışmaya alındı. Kontrol grubu olarak 46 Romatoid Artrit (RA) hastası çalışmaya dahil edildi. Katılımcılara Somatoform Dissosiyasyon Ölçeği (SDÖ), Travma Değerlendirme Ölçeği (TDÖ), Toronto Aleksitimi Ölçeği (TAÖ) ve Çocukluk Çağı Travma Ölçeği (ÇTÖ) uygulandı. Fibromiyalji hastalığının etkisi Fibromiyalji Etki Anketi (FEA) ile ölçüldü.

Bulgular: Fibromiyalji hastalarında en az bir travmatik olay bildiren hasta sayısı $(19, \% 33,9)$ RA grubundan $(6, \% 13)$ yüksek bulundu $(x 2=5,9$, $p=0,015)$. Altı $(\% 10,7)$ FM hastasında TSSB olduğu düşünüldü. Romatoid artrit grubunda TSSB tanı kriterlerini karşılayan hasta yoktu. Travma sonrası stres bozukluğu yaygınlığının FM'de RA grubundan daha yüksek olduğu saptandı. Travmatik yaşantıları olan FM hastalarının FEA skoru travmatik yaşantıları olmayan hastalardan daha yüksekti $(p<0,02)$. Bununla birlikte, analjezik kullanımı ile travmatik yaşantılar arasında pozitif ilişki gözlendi $(r=0,415, p=0,002)$. Fibromiyalji hastalarının ÇTÖ, SDÖ ve TAÖ puanları RA hastalarından anlamlı düzeyde yüksek bulundu.

Sonuç: Bu çalışmada FM hastalarında TSSB, aleksitimi ve dissosiyatif semptomların yaygın olduğu bulundu. Bulgularımız FM hastalarında TSSB, aleksitimi ve dissosiyatif semptomların değerlendirilmesinin hastalık aktivitesi ve ağrı açısından önemli olduğunu göstermektedir. Fibromiyalji hastalarında tedavi stratejileri düzenlenirken psikiyatrik durumlar da değerlendirilmelidir.

Anahtar Kelimeler: Fibromiyalji, travma sonrası stres bozukluğu, aleksitimi, somatoform dissosiyasyon 


\section{Introduction}

Fibromyalgia (FM), which has a prevalence of approximately $2 \%$, is the most common cause of widespread, chronic, musculoskeletal pain in women between 20 and 55 years of age (1). These patients often have multiple somatic concerns and experience difficulty distinguishing joint and muscle pain (2). Knowledge of FM risks factors and pathophysiologic mechanisms is limited (3).

A relationship between FM and mental disorders has been described previously (4-6). Researchers have suggested that anxiety disorders, depression, and alexithymia are more frequently seen in adults with $\operatorname{FM}(7,8)$. Although the etiology of FM is unknown, a number of investigators have reported that physical or emotional trauma may "trigger" FM in susceptible individuals (9). Although a few studies demonstrated that trauma causes FM, trauma may be an initiating or perpetuating factor in FM patients. Patients with FM frequently report a history of physical or psychological trauma before the onset of the illness, and a high frequency of post-traumatic stress disorder (PTSD) and PTSD-like symptoms has been reported in FM patients $(9,10)$.

Post-traumatic stress disorder may contribute to disability and may cause in patients with suffering from pain. In addition, the treatment of PTSD may decrease the severity of pain and pain-related disability (9). Several studies have suggested high rates of childhood trauma in FM patients, with estimates ranging from 32\%-64\% (11-13). Most authors describe a higher trauma prevalence in patients with FM compared with patients with other chronic pain conditions, although this finding is not universal (11-15). Childhood sexual and lifetime sexual and physical abuse as well as lifetime emotional abuse and neglect have been shown to be more prevalent in FM patients $(12-14,16)$. However, a relationship between trauma history and symptom severity may exist (17). Studies suggest that patients reporting childhood abuse experience greater psychological distress; have more severe physical symptoms, greater functional disability, and poorer psychological adjustment; and utilize more health care services (15-18). The high level of stress during and after a trauma may give rise to incomplete or maladaptive processing of the event, which may result in the information-processing deficit known as "dissociation," which is understood as a "disruption of the usually integrated functions of consciousness, memory, identity, or perceptions of the environment" (19). Dissociative symptoms are commonly defined as psychoform and are placed in the domain of memory, identity, consciousness, or perception (20). The somatic sequelae of traumatization affect the sensorimotor organization of traumatic memories and may lead to somatoform symptoms related to the sensory and motor components of the experience (e.g., those related to hearing, seeing, feeling, and speaking) (21).

Somatoform symptoms may also involve pain that requires specific psychotherapeutic treatment. The frequency of these somatoform dissociative symptoms in FM patients is not well established (22). Most interviewing strategies are dependent on the FM patient's ability to identify emotions and precisely label them (23). Alexithymia and PTSD have been frequently reported among patients with chronic pain (24). Additionally, previous studies have found a correlation between alexithymia and PTSD symptoms. Studies have also suggested an association between perceived difficulty in identifying and describing emotional states and the severity of PTSD symptoms $(24,25)$.

Studies on healthy volunteers have shown a positive relationship between alexithymia and measures of pain sensitivity during experimental pain induction $(26,27)$. A similar association has been described in general medical patients, and whether a relationship between alexithymia and experimental pain sensitivity exists in patients with chronic pain remains unclear (28). Additionally, although FM is a common disorder that is associated with a high rate of psychiatric co-morbidities (depression, anxiety disorders), its association with PTSD, alexithymia, and dissociative symptoms has not been sufficiently investigated. Previous studies have examined alexithymia and trauma in patients with FM. However, to our knowledge, there is no study that has evaluated childhood trauma, adulthood trauma, alexithymia, and somatoform dissociation (all together) among these patients.

The present study evaluated three hypotheses:

1) That a high frequency of traumatic experiences and PTSD would be observed in patients with FM.

2) That FM would be associated with symptoms of alexithymia and somatoform dissociation.

3) That trauma negatively affects the clinical parameters of FM.

\section{Material and Methods}

\section{Participants and Study Design}

The study included 56 patients who met the American College of Rheumatology criteria for FM (29). A control group consisting of 46 patients who met the 1987 criteria for rheumatoid arthritis (RA) issued by the American College of Rheumatology was included to address the presence of chronic pain. Subjects with concomitant psychotic disorders or a major medical problem and those who were deemed unable to comprehend and complete the questionnaires in a coherent manner were excluded. Written informed consent was obtained from all subjects, and the study design was approved by the ethics committee of the hospital. All subjects completed a semi-structured interview that assessed sociodemographic and clinical characteristics.

\section{Materials}

Patients (56 FM, 46 RA) completed the Somatoform Dissociation Questionnaire (SDQ), the Posttraumatic Diagnostic Scale (PDS), the Toronto Alexithymia Scale (TAS), and the Childhood Trauma Questionnaire (CTQ).

The impact of FM was measured with the Fibromyalgia Impact Questionnaire (FIQ). In the FIQ, the word "FM" was replaced by "your illness." The FIQ, which measures limitations and physical and psychological well-being, consists of 10 sections. The first section contains 10 questions on activities of daily living, each of which is scored on a Likert-type scale from 0 (always able to do) to 3 (never able to do). Items 4-10 (ability to perform a job, pain, fatigue, morning tiredness, stiffness, 
anxiety, and depression) were measured with $100 \mathrm{~mm}$ visual analog scales (30). The Turkish version of the FIQ was developed by Sarmer et al. (31).

Traumatization was assessed using the PDS. The PDS is designed to determine the severity of PTSD symptoms specified in DSM-IV (American Psychiatric Association, 1994). The scale ranges from 0 ("never") to 3 ("five times per week or more/very severe/nearly always"). The higher the patient scores on the PDS are, the higher the overall severity of PTSD symptoms is. Additionally, if the patient had the minimum number of symptoms described in the DSM-IV, he/she was considered to have PTSD (32). The Turkish version of the PDS was developed by Işıklı (33).

The Childhood Trauma Questionnaire (CTQ) is a 28-item self-report questionnaire that assesses the presence of abuse and neglect. It is a Likert-type questionnaire that measures each type of trauma on a 5-point scale ranging from "never true" to "very often true." It has five subscales (physical, sexual and emotional abuse, and emotional and physical neglect), and a total score can also be obtained (34). The Turkish version of the CTQ was developed by Şar et al. (35).

The Turkish version of the Toronto Alexithymia Scale (TAS) was applied to assess alexithymia and was investigated using the 20 -item version of the TAS, Turkish version. The TAS is a 20 item questionnaire. The three dimensions of the TAS-20 were as follows: 1) difficulty identifying feelings, 2) difficulty describing feelings, and 3) externally oriented thinking (36). The Turkish version of the TAS was developed by Kose et al. (37).

The Somatoform Dissociation Questionnaire (SDQ-20) was used to evaluate somatoform dissociation. The SDQ-20 is a 20item questionnaire that investigates negative symptoms (anesthesia, analgesia, and motor inhibitions) and positive symptoms (localized pain, alternation of taste, and smell preferences/aversions). Five-point scales were used to indicate the degree to which the statements applied. Total scores ranged from 20 to 100. The reliability is of this scale is high, and its construct validity is good (38). The Turkish version of the SDQ was developed by Şar et al. (39).

\section{Statistical Analysis}

SPSS 15.0 statistical program (SPSS, version 15.0 for Windows; SPSS, Chicago, IL, USA) was used for statistical analyses. Continuous variables are presented as means \pm SDs, and categorical variables are presented as percentages. Independent-sample $t$ - and Mann-Whitney U-tests were used to compare FM and RA patients with regard to the study variables. Chi-square tests were used to compare data presented as percentages. Correlation analyses were performed using Pearson's coefficient of correlation. Two-way analysis of variance was used to evaluate the effects of the type of the disease (FMS/RA) and the presence of a trauma history on TAS, SDQ, and CTQ scores. A probability value of $p<0.05$ was considered significant, and two-tailed $p$ values were used for all statistics.

\section{Results}

One hundred two patients (56 FM, $46 \mathrm{RA}$ ) participated in this study. In the FM group, $7.1 \%(n=4)$ was male and $92.9 \%$
Table 1. Sociodemographic characteristics of the sample

\begin{tabular}{|c|c|c|c|c|}
\hline & & $\begin{array}{l}\text { FMS group } \\
\text { n (\%) }\end{array}$ & $\begin{array}{c}\text { RA } \\
\text { group }\end{array}$ & $p$ \\
\hline Age & & $35.1 \pm 6.7$ & $34.5 \pm 9.4$ & 0.77 \\
\hline \multirow[t]{2}{*}{ Gender } & Male & $4(7.1 \%)$ & $6(13 \%)$ & 0.34 \\
\hline & Female & $52(92.9 \%)$ & $40(87 \%)$ & \\
\hline \multirow[t]{4}{*}{ Education level } & Illiterate & $2(3.6 \%)$ & $4(8.7 \%)$ & 0.25 \\
\hline & Elementary school & $29(51.8 \%)$ & $25(54.3 \%)$ & \\
\hline & High school & $11(19.6 \%)$ & $10(21.7 \%)$ & \\
\hline & University & $14(25 \%)$ & $7(15.2 \%)$ & \\
\hline \multirow[t]{3}{*}{ Marital status } & Single & $7(12.5 \%)$ & $12(26.1 \%)$ & 0.17 \\
\hline & Married & $41(73.2 \%)$ & $30(65.2 \%)$ & \\
\hline & Divorced / widowed & $8(14.3)$ & $4(8.7 \%)$ & \\
\hline \multirow[t]{3}{*}{ Level of income } & Low & $10(17.9 \%)$ & $14(30.4)$ & 0.10 \\
\hline & Medium & $34(60.7 \%)$ & $26(56.5)$ & \\
\hline & High & $12(21.4 \%)$ & $6(13.1 \%)$ & \\
\hline $\begin{array}{l}\text { History of } \\
\text { psychiatric } \\
\text { disorder }\end{array}$ & $\begin{array}{l}\text { No } \\
\text { Yes }\end{array}$ & $\begin{array}{l}34(63 \%) \\
20(37 \%)\end{array}$ & $\begin{array}{c}39(84.8 \%) \\
7(15.2 \%)\end{array}$ & $0.014^{*}$ \\
\hline \multirow[t]{4}{*}{ Analgesic use } & No & $8(15.4 \%)$ & $14(30.4 \%)$ & $0.010^{*}$ \\
\hline & $\begin{array}{l}\text { Yes, one or two } \\
\text { times a week }\end{array}$ & $12(23.1 \%)$ & $17(37 \%)$ & \\
\hline & $\begin{array}{l}\text { More than two } \\
\text { times a week }\end{array}$ & $22(42.3 \%)$ & $10(21.7 \%)$ & \\
\hline & Daily & $10(19.2)$ & $5(10.9 \%)$ & \\
\hline
\end{tabular}

${ }^{*} p<0.05$

$(\mathrm{n}=56)$ was female, and the mean age was $35.1 \pm 6.7$ years. In the RA group, $13 \%(n=6)$ was male and $87 \%(n=40)$ was female, and the mean age was $35.5 \pm 9.5$ years. Data on sociodemographic characteristics revealed no significant differences between the groups. Table 1 shows the sociodemographic and clinical features of FM patients and controls.

The number of patients reporting at least one traumatic event was higher in the FM $(19,33.9 \%)$ than in the RA $(6,13 \%)$ $\left(X^{2}=5.9, p=0.015\right)$ group. PTSD was identified in 6 of $56 \mathrm{FM}$ subjects $(10.7 \%)$. In the RA group, no patients met the criteria for PTSD. The current prevalence of PTSD was higher in the FM than the in RA group (Table 2). Of those with FM and traumatic experiences, FIQ scores were higher in patients with than without PTSD $(p=0.02)$.

The average CTQ score was $35.2 \pm 6.7$ in the FM group and $32.4 \pm 4.1$ in the RA group. FM patients had a significantly higher CTQ scores than did patients with RA ( $t=2.4, p=0.018)$. The mean SDQ scores were $38.2 \pm 11.6$ and $33.1 \pm 10.2$ in the FM and RA groups, respectively. Patients with FM had a significantly higher SDQ scores than did patients with RA $(t=2.3, p=0.022)$. The average TAS score was $56.1 \pm 10.5$ in the FM group and $44.8 \pm 10.3$ in the RA group, indicating that patients with FM had significantly higher scores on the TAS than did patients with RA $(t=5.4, p<0.001)$. Table 2 shows the associations among FM, PTSD, dissociative symptoms, and alexithymia. 
Table 2. Psychiatric features of fibromyalgia and control groups

\begin{tabular}{lccc} 
Psychiatric features & $\begin{array}{c}\text { FMS group } \\
\mathbf{n}(\%)\end{array}$ & $\begin{array}{c}\text { RA } \\
\text { group }\end{array}$ & $\mathbf{p}$ \\
\hline Traumatic experiences n (\%) & $19(33.1 \%)$ & $6(13 \%)$ & $0.015^{*}$ \\
Current PTSD n (\%) & $6(10.7 \%)$ & $0(0 \%)$ & 0.27 \\
CTQ score (mean \pm sd) & $35.2 \pm 6.7$ & $31.4 \pm 4.0$ & $0.013^{*}$ \\
Sexual abuse score (mean \pm sd) & $5.6 \pm 1.0$ & $5 \pm 0.3$ & $0.006^{*}$ \\
Physical abuse score (mean \pm sd) & $6.3 \pm 2.1$ & $5.6 \pm 0.7$ & $0.031^{*}$ \\
SDQ score (mean $\pm \mathrm{sd})$ & $38.2 \pm 11.6$ & $33.1 \pm 10.2$ & $0.021^{*}$ \\
TAS score (mean $\pm \mathrm{sd}$ ) & $56.1 \pm 10.5$ & $44.8 \pm 10.3$ & $0.001^{*}$
\end{tabular}

${ }^{*} \mathrm{p}<0.05$

FMS: fibromyalgia syndrome; RA: rheumatoid arthritis; PTSD: post-traumatic stress disorder; CTQ: childhood trauma questionnaire; SDQ: somatoform dissociation questionnaire; TAS: Toronto alexithymia scale


b
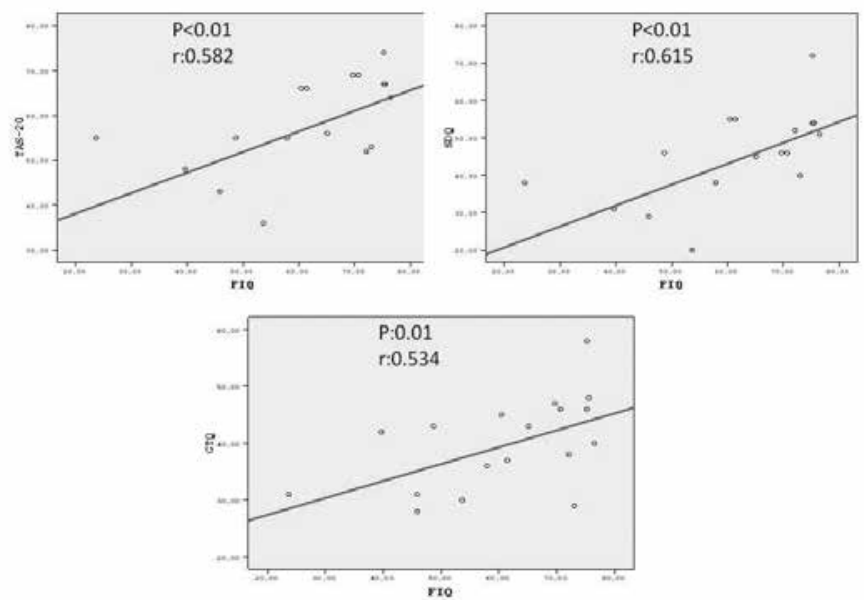

Figure 1. a, b. Correlations between TAS-20 and FIQ, SDQ, and FIQ in FM patients (a). Correlations between TAS-20 and FIQ, SDQ and FIQ, CTQ, and FIQ in FM patients with traumatic experiences (b).

TAS-20: Toronto alexithymia scale-20; FIQ: fibromyalgia impact questionnaire; CTQ: childhood trauma questionnaire; SDQ: somatoform dissociation questionnaire; FM: fibromiyalji

We found significant positive correlations between the FIQ and SDQ scores $(r=0.458, p<0.001)$ and the TAS scores $(r=0.548, p<0.001)$ of patients with FM (Figure $1 \mathrm{a})$. A positive correlation was also observed between FIQ and SDQ scores, and
TAS and CTQ scores were positively correlated in FM patients with traumatic experiences $(r=0.615, p<0.01 ; r=0.582, p<0.01$; $r=0.534, p=0.01$, respectively) (Figure $1 b$ ).

In Fibromyalgia patients, significant differences were found between traumatic experiences and use of analgesics $(p=0.003)$. Additionally, a positive correlation between traumatic experiences and use of analgesics ( $r=0.415, p=0.002)$ was also observed.

Two-way analysis of variance showed significant main effects of type of the disease $(p=0.006)$ and the presence of a trauma history $(p=0.036)$ on TAS score. Two-way analysis of variance showed a significant effect of the presence of a trauma history $(p<0.001)$ but a non-significant main effect of the type of disease $(p=0.073)$ on CTQ score. In contrast, two-way analysis of variance showed a significant effect of the type of disease $(p=0.003)$ but a non-significant main effect of the presence of a trauma history $(p=0.778)$ on SDQ score.

\section{Discussion}

The present study examined associations among trauma, somatoform dissociative symptoms, and alexithymia in patients with FM. Patients with FM reported significantly higher levels of traumatization, somatoform dissociation, and alexithymia, as well as significantly more frequent traumatic experiences, than did RA patients. This study suggests that psychological features negatively affected the clinical parameters of FM. FM has been associated with a history of psychological trauma.

As fibromyalgia syndrome and post-traumatic stress disorder may be associated with similar traumatic experiences, they are frequently comorbid conditions (40). Näring et al. (22) found that more patients with FM $(23,82 \%)$ than with RA $(31,61 \%)$ reported at least one traumatic event. The literature shows increasing evidence of an important relationship between FM and PTSD in patients, and previous studies of adult subjects with PTSD have reported high rates of PTSD (6\%-34\%) in individuals with $\operatorname{FM}(9,11,22)$. Ciccone et al. (41) reported that women with FM were more likely to have intrusive thoughts and arousal and a PTSD diagnosis.

The results of the present study showed that the prevalence of PTSD was higher in patients with FM than in the general population. The present study tested one version of the trauma hypothesis: that sexual trauma is more common in patients with FM. FM may stem from sexual, physical, and/or emotional trauma (13). Childhood trauma may cause a sense of uncertainty resulting in an impairment in coping with the illness (11). The impairment in coping strategies that arises in childhood may negatively affect subsequent FM symptoms (11).

This study showed that patients with FM had higher sexual abuse scores on the CTQ than did patients with RA. Boisset-Pioro et al. (14) showed that childhood sexual abuse was reported more often by female patients with FM than by a comparable group without FM (37\% vs. 22\%). In another study involving female rheumatology patients, Walker et al. (12) showed that patients with FM reported sexual assault (with penetration) more often than did RA patients (33\% vs. $13 \%$ ). However, Taylor et al. (15) failed to find evidence of increased sexual abuse in female patients with FM compared with healthy controls. The difference between studies may relate to the clinical features and 
sociodemographic characteristics of patients and the scales used (self-report or structured clinical interviews). The present study also confirmed that PTSD was more prevalent in the FM group, suggesting that childhood trauma may predispose individuals to the development of FM; future prospective studies are necessary to confirm this hypothesis.

Early trauma may lead to dysregulation of the hypothalamic-pituitary-adrenal (HPA) axis by chronic stress responses (42). Therefore, neuroendocrinological factors are crucial in FM, which has been shown to be associated with sympathetic nervous system and HPA axis abnormalities (43). Hypocortisolemia in FM may be owing to a primary insufficiency of the adrenal gland or to centrally driven hypocortisolism (44). We think that the relationship of trauma and FM and the role of these abnormalities in this relationship should be investigated using hormones and biomarkers.

Possible effects of childhood traumatization have been outlined by recent theories on reactions to traumatic stress. According to these theories, two major patterns can arise in response to trauma: dissociation and hyperarousal. Perry et al. (45) showed that children are more likely than are adults to respond to trauma with dissociation than with hyperarousal. Although this study found a greater prevalence of childhood trauma and subsequent dissociative reactions in those with $\mathrm{FM}$, the results do not explain how trauma leads to the development of FM. In general, women face a higher risk of sexual abuse and are more likely to perceive threats or experience loss of control, and this may enhance their risk of developing PTSD (46).

The present study did not include a control group drawn from the general population or from those with other diseases, but clues regarding the frequency of somatoform dissociation in these populations can be derived from other studies. Patients with FM had moderately higher mean scores on somatoform dissociation than did patients with RA in the present study. Bohn et al. (47) suggested that patients with FM reported high levels of somatoform dissociative symptoms and moderate levels of somatic symptom severity and depression. Näring et al. (22) suggested that patients with FM report significantly higher levels of various forms of traumatization and dissociation than do RA patients. Additionally, a possible dissociative disorder was indicated in $10 \%$ of the FM patients and $2 \%$ of the RA patients. Another study observed psychoform dissociation in $30 \%$ of patients with FM and $7 \%$ of patients with RA and proposed that considerations of dissociation may contribute to a useful perspective for understanding FM (48).

The prevalence of alexithymia among patients with FM patients is unclear $(49,50)$. Sayar et al. (8), studying Turkish patients, found significantly higher alexithymia scores and greater difficulty with communicating feelings among patients with FM compared with those with RA or healthy controls but did not report prevalence rates. Steinweg et al. (51) found that the prevalence of alexithymia in FM patients was significantly higher than in either a group of general medical patients or an RA group. Tuzer et al. (52) reported that alexithymia was linked to psychological attributions in FM patients and that depression, anxiety, and somatization were significantly increased in FM patients with high alexithymia scores. We found that FM patients were more likely to have difficulty identifying and describing feelings and to have higher alexithymia scores than were RA patients. Aguglia et al. (53) showed that the presence of psychiatric symptoms is associated with great impairment in patients with FM syndrome; this psychiatric comorbidity lowers the pain threshold and worsens the patients' quality of life.

We found a positive correlation between FIQ scores and those on the SDQ, TAS, and CTQ. Additionally, we also observed a positive correlation between traumatic experiences and use of analgesics. In a study based on the hypothesis that FM is associated with traumatic experiences.

Eye Movement Desensitization and Reprocessing (EMDR) therapy improved the clinical parameters in FM patients (54). Our findings and those of previous studies support the idea that trauma-focused approaches are important in the treatment of FM.

Several factors must be considered in the interpretation of the results of this study. First, the study sample consisted mostly of women. Thus, our findings may not be sufficiently generalized for each gender. Second, the study sample was relatively small to draw definite conclusions. Third, the diagnosis of PTSD was made by a questionnaire that operationalizes DSM-IV criteria rather than a structured interview, such as SCID-I. In conclusion, PTSD, alexithymia, and somatoform dissociative symptoms are common in patients with FM. The identification and treatment of PTSD, alexithymia, and dissociative symptoms in patients with FM are important and can potentially modify the health status of these individuals.

\section{Conclusion}

Taken together, the results of previous studies with adults and those of the present study suggest that treatment of PTSD, alexithymia, and dissociative symptoms positively influences levels of pain and FM-related disability in patients with FM.

Ethics Committee Approval: Ethics committee approval was received for this study from the ethics committee of Cumhuriyet University School of Medicine (2010-50/71).

Informed Consent: Written informed consent was obtained from patients who participated in this study.

Peer-review: Externally peer-reviewed.

Author Contributions: Concept - M.S., Ö.K.; Design - M.S., Ö.K., H.P; Supervision - Ö.K., E.K.; Funding - H.P., M.S.T.; Data Collection and/or Processing - H.P., M.S.T., Z.Ö., E.A.S.; Analysis and/or Interpretation - M.S., Ö.K., M.S.T.; Literature Review - M.S., Ö.K., H.P., Z.Ö., E.A.S.; Writer - M.S., Ö.K., H.P.; Critical Review - Ö.K., E.K.

Conflict of Interest: No conflict of interest was declared by the authors.

Financial Disclosure: The authors declared that this study has received no financial support. 
Etik Komite Onayı: Bu çalışma için etik komite onayı Cumhuriyet Üniversitesi Tıp Fakültesi'nden alınmıştır (2010-50/71).

Hasta Onamı: Yazılı hasta onamı bu çalışmaya katılan hastalardan/hastanın ailesinden alınmıştır.

\section{Hakem Değerlendirmesi: Dış bağımsız.}

Yazar Katkıları: Fikir - M.S., Ö.K.; Tasarım - M.S., Ö.K., H.P.; Denetleme - Ö.K., E.K. ; Kaynaklar - H.P., M.S.T.; Veri toplanması ve/veya işlemesi - H.P., M.S.T., Z.Ö., E.A.S.; Analiz ve/veya yorum M.S., Ö.K., M.S.T.; Literatür taraması - M.S., Ö.K., H.P., Z.Ö., E.A.S.; Yazıyı yazan - M.S., Ö.K., H.P.; Eleştirel İnceleme - Ö.K., E.K.

Çıkar Çatışması: Yazarlar çıkar çatışması bildirmemişlerdir.

Finansal Destek: Yazarlar bu çalışma için finansal destek almadıklarını beyan etmişlerdir.

\section{References}

1. Lawrence RC, Felson DT, Helmick CG, Arnold LM, Choi H, Deyo RA et al. Estimates of the prevalence of arthritis and other rheumatic conditions in the United States. Arthritis Rheum 2008;58:26-35. [CrossRef]

2. Abeles AM, Pillinger MH, Solitar BM, Abeles M. Narrative review: the pathophysiology of fibromyalgia. Ann Intern Med 2007;146:726-34. [CrossRef]

3. Bellato E, Marini E, Castoldi F, Barbasetti N, Mattei L, Bonasia DE, et al. Fibromyalgia syndrome: etiology, pathogenesis, diagnosis and treatment. Pain Res Treat 2012;2012:426130.

4. Vallejo MA, Rivera J, Esteve-Vives J, Rodríguez-Muñoz MF; Grupo ICAF. Use of the Hospital Anxiety and Depression Scale (HADS) to evaluate anxiety and depression in fibromyalgia patients. Rev Psiquiatr Salud Ment 2012;5:107-14. [CrossRef]

5. Dos Santos EB, Quintans Junior LJ, Fraga BP, Macieira JC, Bonjardim LR. An evaluation of anxiety and depression symptoms in fibromyalgia. Rev Esc Enferm Usp 2012;46:590-6.

6. Wolfe F, Ross K, Anderson J, Russell IJ, Hebert L. The prevalence and characteristics of fibromyalgia in the general population. Arthritis Rheum 1995;38:19-28. [CrossRef]

7. Gormsen L, Rosenberg R, Bach FW, Jensen TS. Depression, anxiety, health-related quality of life and pain in patients with chronic fibromyalgia and neuropathic pain. Eur J Pain 2010;14:127. [CrossRef]

8. Sayar K, Gulec H, Topbas M. Alexithymia and anger in patients with fibromyalgia. Clin Rheumatol 2004;23:441-8. [CrossRef]

9. Cohen H, Neumann L, Haiman Y, Matar MA, Press J, Buskila D. Prevalence of posttraumatic stress disorder in fibromyalgia patients: overlapping syndromes or post-traumatic fibromyalgia syndrome? Semin Arthritis Rheum 2002;32:38-50. [CrossRef]

10. Greenfield S, Fitzcharles M, Esdaile J. Reactive fibromyalgia syndrome. Arthritis Rheum 1992;35:678-81. [CrossRef]

11. Goldberg RT, Pachas WN, Keith D. Relationship between traumatic events in childhood and chronic pain. Disability Rehabil 1999;21:23-30. [CrossRef]

12. Walker EA, Keegan D, Gardner G, Sullivan M, Bernstein D, Katon WJ. Psychosocial factors in fibromyalgia compared with rheumatoid arthritis: II. Sexual, physical and emotional abuse and neglect. Psychosom Med 1997;59:572-7. [CrossRef]

13. Imbierowicz K, Egle UT. Childhood adversities in patients with fibromyalgia and somatoform pain disorder. Eur J Pain 2003;7:113-9. [CrossRef]

14. Boisset-Pioro MH, Esdaile JM, Fitzcharles M. Sexual and physical abuse in women with fibromyalgia syndrome. Arthritis Rheum 1995;38:235-41. [CrossRef]
15. Taylor ML, Trotter DR, Csuka ME. The prevalence of sexual abuse in women with fibromyalgia. Arthritis Rheum 1995;38:229-34. [CrossRef]

16. Alexander RW, Bradley LA, Alarcón GS, Triana-Alexander M, Aaron LA, Alberts KR, et al. Sexual and physical abuse in women with fibromyalgia: association with outpatient health care utilization and pain medication usage. Arthritis Care Res 1998;11:102-15. [CrossRef]

17. McBeth J, Macfarlane GJ, Benjamin S, Morris S, Silman AJ. The association between tender points, psychological distress and adverse childhood experiences: a community-based study. Arthritis Rheum 1999;42:1397-404. [CrossRef]

18. Walen HR, Oliver K, Groessl E, Cronan TA, Rodriguez VM. Traumatic events, health outcomes, and health care use in patients with fibromyalgia. Journal of Musculoskeletal Pain 2001;9:19-38. [CrossRef]

19. Heaton P, Davis RE, Happé FG. Research note: exceptional absolute pitch perception for spoken words in an able adult with autism. Neuropsychologia 2008;46:2095-8. [CrossRef]

20. Kihlstrom JF, Glisky ML, Angiulo MJ. Dissociative tendencies and dissociative disorders. J Abnorm Psychol 1994;103:117-24. [CrossRef]

21. van der Hart O, van Dijke A, van Son M, Steele K. Somatoform dissociation in traumatized World War I combat soldiers: A neglected clinical heritage. J Trauma Dissociation 2000;1:33-66. [CrossRef]

22. Näring GW, van Lankveld W, Geenen R. Somatoform dissociation and traumatic experiences in patients with rheumatoid arthritis and fibromyalgia. Clin Exp Rheumatol 2007;25:872-7.

23. Lesser IM. Current concepts in psychiatry. Alexithymia. N Engl J Med 1985;312:690-2. [CrossRef]

24. Lumley MA, Smith JA, Longo DJ. The relationship of alexithymia to pain severity and impairment among patients with chronic myofascial pain: comparisons with self-efficacy, catastrophizing, and depression. J Psychosom Res 2002;53:823-30. [CrossRef]

25. Frewen PA, Lanius RA, Dozois DJ, Neufeld RW, Pain C, Hopper JW, et al. Clinical and neural correlates of alexithymia in posttraumatic stress disorder. J Abnorm Psychol 2008;117:171-81. [CrossRef]

26. Nyklícek I, Vingerhoets AJ. Alexithymia is associated with low tolerance to experimental painful stimuli. Pain 2000;85:471-5. [CrossRef]

27. Kano M, Hamaguchi T, Itoh M, Yanai K, Fukudo S. Correlation between alexithymia and hypersensitivity to visceral stimulation in human. Pain 2007;132:252-63. [CrossRef]

28. Jackson T, Nagasaka T, Fritch A, Gunderson J. Alexithymia is not related to tolerance for cold pressor pain. Percept Mot Skills 2002;94:487-8. [CrossRef]

29. Wolfe F, Smythe HA, Yunus MB, Bennett RM, Bombardier C, Goldenberg $\mathrm{DL}$, et al. The American College of Rheumatology 1990 Criteria for the Classification of Fibromyalgia. Report of the Multicenter Criteria Committee. Arthritis Rheum 1990;33:160-72. [CrossRef]

30. Burckhardt CS, Clark SR, Bennett RM. The fibromyalgia impact questionnaire: development and validation. J Rheumatol 1991;18:728-33.

31. Sarmer S, Ergin S, Yavuzer G. The validity and reliability of the Turkish version of the Fibromyalgia Impact Questionnaire. Rheumatol Int 2000;20:9-12. [CrossRef]

32. Norris $\mathrm{AE}$, Aroian $\mathrm{KJ}$. Assessing reliability and validity of the Arabic language version of the Post-traumatic Diagnostic Scale (PDS) symptom items. Psychiatry Res 2008;160:327-34. [CrossRef]

33. Işıklı S. Travma Sonrası Stres Belirtileri Olan Bireylerde Olaya Ilişkin Dikkat Yanlılığı, Ayrışma Düzeyi ve Çalışma Belleği Uzamı Arasındaki Iliş̧kiler. Yayınlanmamış Doktora Tezi, Hacettepe Üniversitesi Sosyal Bilimler Enstitüsü, Ankara, 2006.

34. Bernstein D, Fink L. Childhood Trauma Questionnaire: A Retrospective Self-Report. San Antonio: The Psychological Corporation; 1998.

35. Şar V, Öztürk E, Ikikardeş E. Çocukluk Çağı Ruhsal Travma Ölçeğinin Türkçe Uyarlamasının Geçerlilik ve GüvenilirliğiTurkiye Klinikleri J Med Sci 2012;32:1054-63. 
36. Bagby RM, Taylor GJ, Parker JD. The Twenty-item Toronto Alexithymia Scale-Il. Convergent, discriminant and concurrent validity. J Psychosom Res 1994;38:33-40. [CrossRef]

37. Kose S, Sayar K, Gulec H, Evren C, Borckardt J. The Turkish version of the 20-Item Toronto Alexithymia Scale (TAS-20): reliability, validity, and factorial structure. Society of Biological Psychiatry Symposium, Atlanta, GA 2005;5:19-22.

38. Nijenhuis E, Spinhoven P, van Dyck R, van der Hart O, Vanderlinden J. Psychometric characteristics of the somatoform dissociation questionnaire: a replication study. Psychother Psychosom 1998;67:17-23. [CrossRef]

39. Oishi K, Sar B, Wada A, Hidaka Y, Matsumoto S, Amano H, et al. Nitrite reductase from Pseudomonas aeruginosa induces inflammatory cytokines in cultured respiratory cells. Infect Immun 1997;65:2648-55.

40. Häuser W, Galek A, Erbslöh-Möller B, Köllner V, Kühn-Becker H, Langhorst J, et al. Posttraumatic stress disorder in fibromyalgia syndrome: prevalence, temporal relationship between posttraumatic stress and fibromyalgia symptoms, and impact on clinical outcome. Pain 2013;154:1216-23. [CrossRef]

41. Ciccone DS, Elliott DK, Chandler HK, Nayak S, Raphael KG. Sexual and physical abuse in women with fibromyalgia syndrome: a test of the trauma hypothesis. Clin J Pain 2005;21:378-86. [CrossRef]

42. Winfield JB. Pain in fibromyalgia. Rheumatic Dis Clin North Am 1999;25:55-79. [CrossRef]

43. Crofford LJ, Young EA, Engleberg NC, Korszun A, Brucksch CB, McClure LA, et al. Basal circadian and pulsatile ACTH and cortisol secretion in patients with fibromyalgia and/or chronic fatigue syndrome. Brain Behav Immun 2004;18:314-25. [CrossRef]

44. Lentjes EG, Griep EN, Boersma JW, Romijn FP, de Kloet ER. Glucocorticoid receptors, fibromyalgia and low back pain. Psychoneuroendocrinology 1997;22:603-14. [CrossRef]
45. Perry BD, Pollard R. Homeostasis, stress, trauma, and adaptation. A neurodevelopmental view of childhood trauma. Child Adolesc Psychiatr Clin N Am 1998;7:33-51.

46. Olff M, Langeland W, Draijer N, Gersons B. Gender differences in posttraumatic stress disorder. Psychol Bull 2007;133:183-204. [CrossRef]

47. Bohn D, Bernardy K, Wolfe F, Häuser W. The association among childhood maltreatment, somatic symptom intensity, depression, and somatoform dissociative symptoms in patients with fibromyalgia syndrome: a single-center cohort study. J Trauma Dissociation 2013; 14:342-58. [CrossRef]

48. Leavitt F, Katz RS. The dissociative factor in symptom reports of rheumatic patients with and without fibromyalgia. J Clin Psychol 2003;10:259-66.

49. Brosschot JF, Aarsse HR. Restricted emotional processing and somatic attribution in fibromyalgia. Int J Psychiatry Med 2001;31:12746. [CrossRef]

50. Malt EA, Olafsson S, Lund A, Ursin $\mathrm{H}$. Factors explaining variance in perceived pain in women with fibromyalgia. BMC Musculoskeletal Disord 2002;3:12. [CrossRef]

51. Steinweg DL, Dallas AP, Rea WS. Fibromyalgia: unspeakable suffering, a prevalence study of alexithymia. Psychosomatics 2011;52:255-62. [CrossRef]

52. Tuzer V, Dogan Bulut S, Bastug B, Kayalar G, Göka E, Beştepe E. Causal attributions and alexithymia in female patients with fibromyalgia or chronic low back pain. Nord J Psychiatry 2011;65:138-44. [CrossRef]

53. Aguglia A, Salvi V, Maina G, Rossetto I, Aguglia E. Fibromyalgia syndrome and depressive symptoms: comorbidity and clinical correlates. J Affect Disord 2011;128:262-6. [CrossRef]

54. Kavakcı Ö, Semiz M, Kaptanoğlu E, Özer Z. Fibromiyaljide EMDR'nin etkinliğinin araştırılması: Yedi olguyu içeren bir klinik çalışma. Anadolu Psikiyatri Derg 2012;13:75-81. 